\title{
Forecasting of wheat yield in various agro-climatic regions of Bihar by using CERES-Wheat model
}

\section{P.K.SINGH* ${ }^{*}$ K.K.SINGH, PRIYANKA SINGH, R. BALASUBRAMANIAN ${ }^{1}$, A.K.BAXLA, B.KUMAR ${ }^{2}$, AKHILESH GUPTA ${ }^{3}$, L.S.RATHORE and NAVEEN KALRA ${ }^{4}$}

Agro Advisory Service Division, India Meteorological Department, New Delhi-110003

${ }^{1}$ Agrimet Division, IMD, Pune-411005

${ }^{2}$ Bihar Agricultural University, Sabour-813210, Bihar

${ }^{3}$ Department of Science and Technology, New Delhi-110016

${ }_{4}^{4}$ Indian Agricultural Research Institute, New Delhi-110012

*e mail: pksingh66@gmail.com

\begin{abstract}
Forecasting yield of crops is important for planners in taking tactical decisions for ensuring food availability. Crop simulation models are useful tool to forecast the crop yield. The CERES-wheat model calibrated and validated with experimental data was used to predict the district wise yield in Bihar. Based on the areas under different dates of sowing and crop cultivars, a correction factor was applied on simulated yield to predict the district wise and regional wheat yield. The simulated yield were higher than the actual yield in all the three agro-climatic zones, while the forecasted yields were very close to actual. The percentage deviation of the forecasted yield from the actual was $\pm 4.0 \%$. The results clearly indicated that the CERES-Wheat model can be used to regional production estimates of wheat in Bihar.
\end{abstract}

Keywords: DSSAT v 4.6 model, weather data, simulated yield, forecasted $\&$ actual yields

Forecasting of wheat yield, well in advance, is important for policy makers in the government for further course of action and planning. Directorate of Economics and Statistics releases estimates of area, production and yield in respect of 51 principal crops of food grains, oilseeds, sugarcane, fibers and important commercial and horticulture crops (Anonymous, 2010). These crops together accounts for nearly $87 \%$ of agriculture output and contribute significantly in the GDP for Bihar. Forecasting Agricultural output using Space, Agro-Meteorology and Land based observations (FASAL) Network is important from view point of regional yield estimates (Ghosh et al., 2014).

Crop simulation models, by integrating agronomic and inputs management and weather can provide reliable forecast of crop yield in advance (Agrawal and Mehta, 2007). In the present study, forecasting of wheat yield on regional basis by using crop simulation model (CERESWheat) and integrating agronomic and management inputs have been done for different agro-climatic zones of Bihar.

\section{MATERIALAND METHODS}

CERES-Wheat model has been used for simulating wheat yield in various locations in three agro-ecological zones of Bihar viz. North west alluvial plain zone (NW APZ), South alluvial plain zone (SAPZ) and North east alluvial plain zone (NEAPZ). Data sets were compiled from Agromet Field Units, RAU and Pusa under FASAL project for years 2007-12 for validation of the model. Cultivar's coefficients for the test varieties (HD2824, HD2733 and PBW-343), in terms of genetic, physiological and phenological behavior were evolved through run of GLUE sub-routine of DSSAT. District wise weather data were obtained from Agromet Service Cell, IMD, New Delhi and Agromet Field Units of Bihar representing different agroclimatic zones.

\section{Forecasting of regional wheat yield}

The simulated yield is a point application and has limitation of capturing variations in soil, weather, inputs and other biotic/abiotic stresses, which are generally higher on regional/district scale. The point run from the model needs to be compared with the actual regional productivity (by use of historic data) and subsequently generating a correction factor for toning the simulation result down to realistically match with the actual value. A correction factor is applied to reduce the difference between simulated and observed

*Present Address: CDM, LBSNAA, Mussoorie 
Table 1: Progress of wheat area sowing window (average of last five seasons) used in the present study (irrespective of test cultivars)

\begin{tabular}{llr}
\hline Sowing Date & Cultivars & Area covered (\%) \\
\hline 15 Nov & HD2824 & 10 \\
$25 \mathrm{Nov}$ & HD2733 & 35 \\
$5 \mathrm{Dec}$ & PBW-343 & 40 \\
$15 \mathrm{Dec}$ & HD2733 & 10 \\
$25 \mathrm{Dec}$ & PBW-343 & 5 \\
Total & & 100 \\
\hline
\end{tabular}

Table 2: Genetic co-efficient for test cultivars of wheat by using GLUE module of DSSATv4.6

\begin{tabular}{lrrr}
\hline Coefficients & HD 2824 & HD 2733 & PBW-343 \\
\hline P1V & 20 & 20 & 20 \\
P1D & 72 & 88 & 70 \\
P5 & 600 & 650 & 800 \\
G1 & 20 & 18 & 20 \\
G2 & 40 & 35 & 45 \\
G3 & 1.5 & 1.5 & 1.5 \\
PHINT & 95 & 95 & 95 \\
\hline
\end{tabular}

yield. On the basis of historic datasets, correction factor for each district was computed.

Methodology developed in the present study to run the model for different dates of sowing and working out the weighted mean yield of wheat depending upon the per cent area covered under each date of sowing (Table 1). The simulated yield was compared with the district yield, averaged over the past few years, to get the correction factor, which subsequently would be utilized to get the forecasted yield in the test years.

For the pre harvest (F3) yield predication for year 2012-13, the actual data at all the locations was taken up till date (preferably at flowering- the forecast time) and subsequent use of one-week ( 7 days) medium range weather forecast (MRFs) and thereafter (45 days) daily extended range weather forecast (ERFs) normal data to complete the crop cycle.

\section{RESULTS AND DISCUSSION}

The genetic coefficients (Table 2) were validated with the field experimental data for test cultivars of wheat grown under different production environments. The performance of the model was evaluated and validated

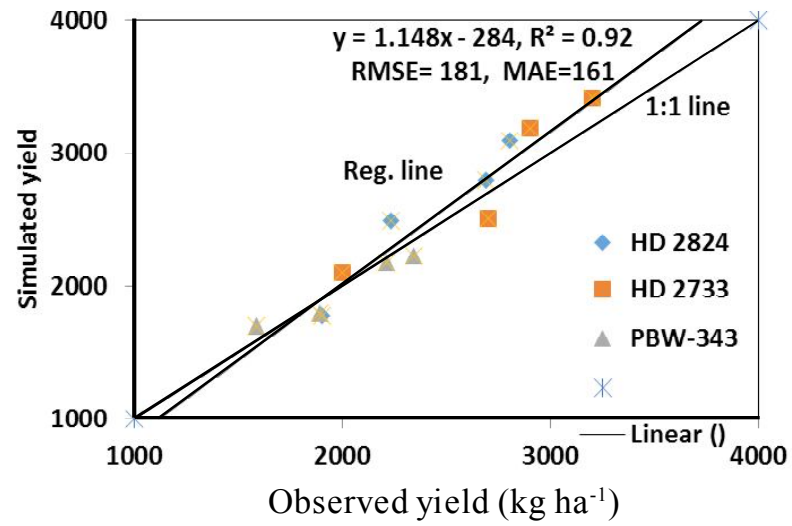

Fig. 1: Validation of CERES-Wheat (DSSAT Ver. 4.6) for yield of wheat of different cultivars.

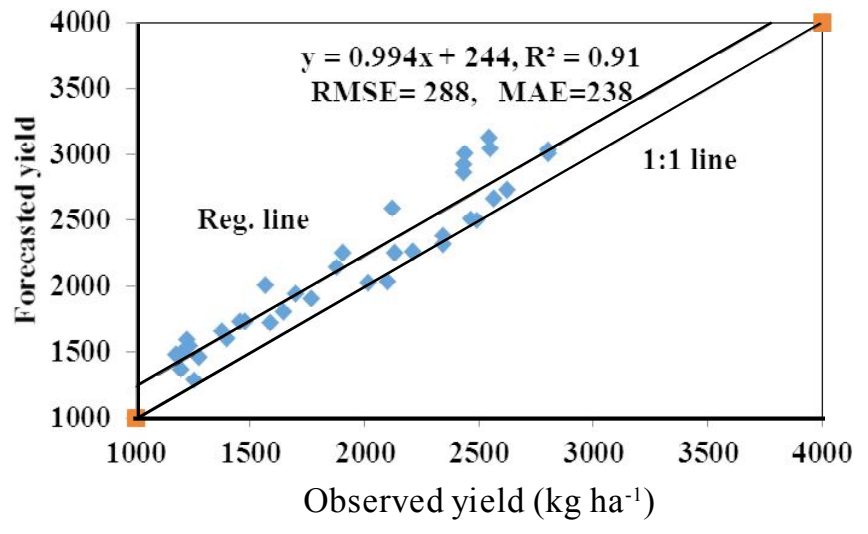

Fig 2: Observed and forecast yields $\left(\mathrm{kg} \mathrm{ha}^{-1}\right)$ of wheat in different district- wise in Bihar during 2012-13)

through yield response of wheat, which was satisfactory as seen through 1:1 line and regression line (Fig. 1). Simulated yields, in general, were slightly overestimated, but the deviation was not much and the regression line more or less matched with the 1:1 line. The values of RMSE, MAE and correlation coefficient were $181 \mathrm{~kg} \mathrm{ha}^{-1}, 161 \mathrm{~kg} \mathrm{ha}^{-1}$ and 0.92 (92\%), respectively. The results indicated that the calibrated CERES-Wheat model can be used for forecasting of wheat yield in different agro-climatic zones of Bihar.

The year wise simulated, forecasted and actual yield averaged over all the locations are also presented in Table 3. Among the different zones, the simulated yield was maximum $\left(3869 \pm 373 \mathrm{~kg} \mathrm{ha}^{-1}\right)$ at Pusa (NWAPZ) and lowest $\left(3208 \pm 269 \mathrm{~kg} \mathrm{ha}^{-1}\right)$ at Sabour, while the forecasted yield was maximum at Sabour $\left(2095 \pm 572 \mathrm{~kg} \mathrm{ha}^{-1}\right)$ and lowest at Pusa $\left(1517 \pm 373 \mathrm{~kg} \mathrm{ha}^{-1}\right)$. It is also seen that the forecasted yield was very close to observed yield during 2007-08 to 2011-12 with per cent error of only \pm 4 . The observed and forecasted yield in different districts (Fig. 2) was very close with coefficient of determination of 0.91 and RMSE of 288 
Table 3: Mean simulated and derived forecasted yields $\left(\mathrm{kg} \mathrm{ha}^{-1}\right)$ using DSSAT v4.6 model in the test Agro-climatic Zones

\begin{tabular}{|c|c|c|c|}
\hline Agro-climatic Zone & Parameters & Simulated $\left(\mathrm{kg} \mathrm{ha}^{-1}\right)$ & Forecasted $\left(\mathrm{kg} \mathrm{ha}^{-1}\right)$ \\
\hline North West Alluvial & Mean & 3869 & 1517 \\
\hline Plain Zone (NWAPZ):- & SD & 372.9 & 372.9 \\
\hline Station- Pusa & $\mathrm{CV}(\%)$ & 9.6 & 24.6 \\
\hline \multirow{3}{*}{$\begin{array}{l}\text { South Alluvial Plain Zone } \\
\text { (SAPZ):- Station-Sabour }\end{array}$} & Mean & 3208 & 2095 \\
\hline & $\mathrm{SD}$ & 259.8 & 572.4 \\
\hline & $\mathrm{CV}(\%)$ & 8.1 & 27.3 \\
\hline \multirow{3}{*}{$\begin{array}{l}\text { North East Alluvial Plain Zone } \\
\text { (NEAPZ):- Station- Agwanpur }\end{array}$} & Mean & 3735 & 1912 \\
\hline & $\mathrm{SD}$ & 134.9 & 135.0 \\
\hline & $\mathrm{CV}(\%)$ & 3.6 & 7.1 \\
\hline \multirow[t]{4}{*}{ Average } & Mean & 3604 & 1841 \\
\hline & $\mathrm{SD}$ & 415.9 & 495.9 \\
\hline & $\mathrm{CV}(\%)$ & 11.5 & 26.9 \\
\hline & \multicolumn{3}{|c|}{ Model Performance (averaged over test locations) } \\
\hline Year & Simulated $\left(\mathrm{kg} \mathrm{ha}^{-1}\right)$ & Forecasted $\left(\mathrm{kg} \mathrm{ha}^{-1}\right)$ & Observed $\left(\mathrm{kg} \mathrm{ha}^{-1}\right)$ \\
\hline 2007-08 & 3739 & 1387 & 1207 \\
\hline 2008-09 & 3851 & 1499 & 1316 \\
\hline $2009-10$ & 4099 & 1747 & 1689 \\
\hline $2010-11$ & 3548 & 1196 & 1282 \\
\hline $2011-12$ & 4096 & 1744 & 1426 \\
\hline Mean & 3866 & 1515 & 1404 \\
\hline $\mathrm{SD}\left(\mathrm{kg} \mathrm{ha}^{-1}\right)$ & 236.9 & 236.9 & 198.4 \\
\hline CV $(\%)$ & 6.1 & 15.6 & 14.1 \\
\hline Percent error & \pm 4 & & \\
\hline
\end{tabular}

$\mathrm{kg} \mathrm{ha}^{-1}$. Thus the model can be used in predicting the district wise as well as regional yield of wheat in different alluvial plain zones of Bihar. The results clearly revealed the capability of the simulation model to forecast the wheat yield by incorporating the variability in other unaddressed factors with the simulation results. Thus the result show the performance of the methodology of yield forecast over different agro-climatic zones, and the averaged results over seasons and the results clearly revealed satisfactory performance of the approach in yield estimates on district as well as regional scales. The findings were in agreement with the results reported by Singh et al., (2015 a \& b).

\section{CONCLUSION}

The study indicated that DSSAT $v 4.6$ is a strong tool for prediction of yield in advance, with the introduction of the correction factor to transform the point based results to regional/districts scales. There is a need to create databases for relational layers of bio-physical and socio-economic aspects for the growing regions to be subsequently integrated with the crop simulation results for regional estimates.

\section{REFERENCES}

Agrawal, R. and Mehta, S.C. (2007). Weather based forecasting of crop yields, pests and diseases-IASRI models, J. Ind. Soc. Agri. Stat., 61(2): 255-263.

Anonymous (2010). Directorate of Economics and Statistics, Department of Agriculture and Cooperation, India.

Ghosh, K., Balasubramanian, R, Banopadhyay, S., Chattopadhyay, N., Singh, K.K. and Rathore, L.S. (2014). Development of cropyield forecastmodelsunderFASALa case study of kharif rice in West Bengal, $J$. Agrometeorol., 16(1):1-8.

Singh, P. K., Singh, K. K., Bhan, S. C., Baxla, A. K., Gupta, A., 
Balasubramanian, R. and Rathore, L. S. (2015a). Growth and yield prediction of rice DSSATv4.5 model for the climate conditions of South Alluvial Zone of Bihar (India). J. Agrometeorol., 17(2):194-198.
Singh, P.K., Singh, K. K., Baxla, A. K. and Rathore, L. S. (2015b). Impact of Climatic Variability on Wheat Predication using DSSATv4.5 (CERES-Wheat) Model for the different Agroclimatic zones in India, Springer, pp 4555 . 